\title{
Molecular analysis of the eighteen most frequent mutations in the BRCA1 gene in 63 Chilean breast cancer families
}

\author{
LILIAN JARA ${ }^{1}$, SANDRA AMPUERO ${ }^{2}$, EUDOCIA SANTIBÁÑEZ ${ }^{1}$, \\ LORENA SECCIA $^{3}$, JUAN RODRÍGUEZ ${ }^{1}$, MARIO BUSTAMANTE ${ }^{1}$ \\ GUILLERMO LAY-SON ${ }^{1}$, JOSÉ MANUEL OJEDA ${ }^{2}$, \\ JOSÉ MIGUEL REYES ${ }^{3}$ and RAFAEL BLANCO ${ }^{1}$.
}

\footnotetext{
${ }^{1}$ Human Genetics Program, Institute of Biomedical Sciences, School of Medicine, University of Chile, Santiago, Chile.

${ }^{2}$ Center for Cancer Prevention, School of Medicine, University of Chile, Santiago, Chile.

${ }^{3}$ Corporación Nacional del Cáncer (CONAC), Santiago, Chile.
}

\begin{abstract}
BRCAl gene mutations account for nearly all families with multiple cases of both early onset breast and/or ovarian cancer and about $30 \%$ of hereditary breast cancer. Although to date more than 1,237 distinct mutations, polymorphisms, and variants have been described, several mutations have been found to be recurrent in this gene. We have analyzed 63 Chilean breast/ovarian cancer families for eighteen frequent $B R C A 1$ mutations. The analysis of the five exons and two introns in which these mutations are located was made using mismatch PCR assay, ASO hybridization assay, restriction fragment analysis, allele specific PCR assay and direct sequentiation techniques. Two BRCAl mutations (185delAG and C61G) and one variant of unknown significance (E1250K) were found in four of these families. Also, a new mutation (4185delCAAG) and one previously described polymorphism (E1038G) were found in two other families. The $185 \mathrm{delAG}$ was found in a $3.17 \%$ of the families and the others were present only in one of the families of this cohort. Therefore these mutations are not prominent in the Chilean population. The variant of unknown significance and the polymorphism detected could represent a founder effect of Spanish origin.
\end{abstract}

Key terms: BRCAl gene; frequent mutations; polymorphism; 4185delCAAG; new mutation; Chilean population.

\section{INTRODUCTION}

Breast cancer is the second most common malignancy among women in developing countries (Parkin, 1994). In Chile its actual incidence has not been accurately established given that the obligation to notify of occurrences of this disease is yet not mandatory. Recent studies in Chile have established that breast cancer constitutes the second highest mortality rate after stomach cancer, showing even higher mortality rates than cervical cancer, according to the Instituto Nacional de Estadísticas de Chile, (National Institute of
Statistics, 1999). Female mortality rates due to breast cancer in Chile have increased steadily and as of 1995 had reached 11.7 per 100.000 (Peralta et al., 1995).

A family history of breast and/or ovarian cancer is one of the main risk factors for the development of these diseases (Lynch, 1981). It has been estimated that $5-10 \%$ of all breast cancers are hereditary and attributable to mutations in several highly penetrant susceptibility genes from which only two have been identified: BRCAI (OMIM 113705) and BRCA2 (OMIM $600185)$. 
The mutational spectrum in BRCAl is very broad, with hundreds of different mutations reported worldwide. Since its isolation, more than 1,237 distinct germ-line mutations, polymorphisms, and variants have been described in the Breast Cancer Information Core Database (BIC). Although there is a large number of distinct mutations, the proportion of families with mutations in $B R C A 1$ and BRCA2 strongly depends upon the populations analyzed (Szabo and King, 1997) and the specific characteristics of the selected families (Serova et al., 1997; Schubert et al., 1997; Malone et al., 1998; Ford et al., 1998, Nathanson et al., 2001). BRCA1 mutation studies have been reported in different ethnic groups (Panguluri et al., 1999; Ruiz-Flores et al., 2002; Saxena et al., 2002; Zhi et al., 2002; Manguoglu et al., 2003). There have been extensive molecular analyses of the BRCAl mutations performed in Caucasian populations in countries such as Canada, USA, UK, Sweden, Netherlands, Belgium, Norway, and Spain (Simard et al., 1994; Gayther et al., 1995; Shattuck-Eidens et al., 1995; Johannsson et al., 1996; Peelen et al., 1997; Claes et al., 1999; Borg et al., 1999; Neuhausen., 2000; Osorio et al., 2000; Llort et al., 2002; Vega et al., 2002; Durán et al., 2003; de Sanjose et al., 2003; Díez et al., 2003). BRCA1 mutations have been reported in Japanese (Inoue et al., 1995; Matsushima et al., 1995; Katagiri et al., 1996; Miki et al., 1996), Taiwanese (Li et al., 1999), other Asian populations (BIC), and in African Americans (Panguluri et al., 1999).

It is of clinical and epidemiological importance to characterize the profile of the mutations in the BRCAI and BRCA2 genes in populations originating from outside the extensively studied European, North American, and Australian gene pool. Knowledge of the BRCA1 and BRCA2 gene mutations in the Chilean population is relatively scant.

The contemporary Chilean population stems from the admixture of Amerindian peoples (Mongoloid) with the Spanish invaders (European Caucasian) initiated in the $16^{\text {th }}$ and $17^{\text {th }}$ centuries. Later migrations (19 ${ }^{\text {th }}$ century) of Germans, Italians, Arabs, and Croatians have had only a minor impact on the overall population (not more than
$4 \%$ of the total) and are restricted to the specific locations of the country where they settled (Encina, 1983; Cruz-Coke, 1976; Valenzuela and Harb, 1977). The relationship between ethnicity, Amerindian admixture, genetic markers, and socioeconomic strata has been extensively studied in Chile (Valenzuela and Harb, 1977; Valenzuela et al., 1987; Valenzuela, 1988; Palomino et al., 1990; Palomino et al., 1991). These reports have demonstrated that the degree of Amerindian admixture can be determined by the frequencies of the alleles of $\mathrm{ABO}$ and $\mathrm{Rh}$ loci.

In the present study, we have analyzed 63 Chilean families at high-risk for hereditary breast cancer in order to screen eighteen BRCAl mutations. The mutations were selected because: a) they are present in the Amerindian and/or in the Spanish settlers which gave origin to the actual admixed Chilean population, and b) the high number of records of the selected mutations in the BIC database. As BRCAl is associated with an increase in risk for breast and other types of cancer, the identification of mutations in this gene has significant implications for the medical management of breast cancer patients and their family members.

\section{METHODS}

\section{Subjects}

In this study, 63 high-risk families were selected from the files of the Central Metropolitan Health Service of Santiago, Corporación Nacional del Cáncer (CONAC), and the Arturo López Pérez Foundation (Table I). The families included were required to comply with at least one of the following criteria: 1) families with at least two first degree relatives with breast and/or ovarian cancer diagnosed at any age, 2) families with at least two first or second degree relatives with breast cancer diagnosed before age 50,3) families with at least three first or second degree relatives with breast cancer, at least one of whom was diagnosed before age 40, 4) families with at least one member having a cancer 
TABLE I

Chilean breast cancer families at high risk for breast cancer predisposing mutations

\begin{tabular}{lcc}
\hline Case category for selection & $\begin{array}{c}\text { Mean age at diagnosis } \\
\text { of individual (years) }\end{array}$ & $\begin{array}{c}\text { Number of families } \\
(\% \text { total families })\end{array}$ \\
\hline Multiple case families $\left(\geq 4^{\mathrm{a}}\right)$ & 48.81 & $25(39.6 \%)$ \\
Multiple-case families $\left(3^{\mathrm{a}}\right)$ & 51.12 & $19(30.2 \%)$ \\
Multiple-case families $\left(2^{\underline{a}}\right)$ & 46.13 & $3(4.8 \%)$ \\
Early onset $(\leq 30$ years) breast cancerc & 28.33 & $63(100 \%)$ \\
Total & 43.60 & \\
\hline
\end{tabular}

a: Number of breast cancer cases per family, including first-degree, second-degree, and distant relatives.

b: Mean age at onset of all individuals in the family affected with breast and/or ovarian cancer (whether sampled or not).

c: Families with one case of breast cancer diagnosed before age 30 (criteria №7 Methods)

diagnosed before age 50 and at least one member with ovarian cancer diagnosed at any age, 5) families with at least one case of male breast cancer diagnosed at any age and at least one case of female breast cancer diagnosed at any age, 6) families with three or more different cancers (female or male breast cancer, ovarian, prostate, pancreas and larynx in non-smoking individuals), 7) families with at least one breast cancer diagnosed before age 30 , and 8 ) families with at least one case of bilateral breast cancer.

In the selected families $9.5 \%(6 / 63)$ had bilateral breast cancer; $3.2 \%(2 / 63)$ had both breast and ovarian cancer and $1.6 \%$ $(1 / 63)$ presented male breast cancer. Of the 63 families, 70 women affected with breast cancer (probands) participated in this study. From these women, $31.43 \%(22 / 70)$ had early age onset ( $\leq 40$ years) of diagnosis with a mean age of 31.9 years. There was no upper or lower age cut-off for breast cancer cases. Breast cancer was verified by the original pathology report for all probands, but not for all affected relatives.

Genomic DNA (gDNA) was extracted from peripherical blood lymphocytes of 70 probands and 98 healthy relatives belonging to the cohort of the 63 families. Samples were obtained according to the method described by Chomczynsky and Sacchi (1987). The DNA samples were screened for the 18 most frequent germ-line $B R C A 1$ mutations (Table II) which were selected using two criteria: a) the mutations are present in the Amerindian and/or in the Spanish settlers which originated the actual admixed Chilean population, and b) the high number of records of these mutations in the BIC database. The methods used were mismatch polymerase chain reaction (mismatch PCR); allele-specific oligonucleotide (ASO) hybridization; restriction fragment analysis, allele specific PCR assay and direct sequencing. In each mutation, we used molecular weight markers and mutated samples as positive controls, which were kindly provided by Dr. Sabine Pages, Curie Institute, Paris, France, and Dr. Larry Brody, NIH, USA.

\section{Mismatch PCR assay}

The BRCA1 185delAG (Exon 2), 1675delA (Exon 11b), E1250X (Exon 11d), R1443X (Exon 13) and 5382insC (Exon 20) mutations, were identified by a mismatch PCR assay using primers shown in Table IIIA. This assay introduces a mismatch into the primers of each of the mutations analyzed. As a result, the PCR product of the normal allele acquires a restriction site that the mutant allele does not have. The acquired restriction site allows us to confirm the presence of the mutant alleles. For the 
analysis of the $185 \mathrm{delAG}$ and $5382 \mathrm{insC}$ mutations we used the primers and conditions described by Abeliovich et al., (1997) and Backe et al., (1998) respectively. For the other mutations, amplifications were in $50 \mu \mathrm{l}$ reactions containing 200ng of gDNA, $1.5 \mathrm{mM} \mathrm{MgCl}_{2}, 50 \mathrm{mM} \mathrm{KCl}, 10 \mathrm{mM}$ Tris- $\mathrm{HCl}, \mathrm{pH} 9.0,0.2 \mathrm{mM}$ of dNTPs, 40 pmoles of primers (Table IIIA) and 1.5 U Taq DNA polymerase (Promega). PCR conditions were $95^{\circ} \mathrm{C}$ for $5 \mathrm{~min}$ followed by
30 cycles of $1 \mathrm{~min}$ at $94^{\circ} \mathrm{C}, 1 \mathrm{~min}$ at $55^{\circ} \mathrm{C}, 1$ min at $72^{\circ} \mathrm{C}$, and $10 \mathrm{~min}$ at $72^{\circ} \mathrm{C}$. The PCR products were digested with restriction endonucleases following the conditions described by suppliers (New England Biolabs) and the fragments were resolved on agarose gels, and/or $5 \%$ denaturing sequence gels and silver staining. Table IIIA also shows the restriction enzymes and the sizes of the PCR products after digestion with the restriction enzyme used in each case.

TABLE II

Most Frequent BRCAl Mutations ${ }^{\mathrm{a}}$

\begin{tabular}{|c|c|c|c|c|c|c|c|}
\hline Exon & NT & Codon & $\begin{array}{l}\text { Base } \\
\text { Change }\end{array}$ & $\begin{array}{c}\text { AA } \\
\text { Change }\end{array}$ & Designation & $\begin{array}{l}\text { Mutation } \\
\text { Type }\end{array}$ & $\begin{array}{c}\text { Mutation } \\
\text { Effect }\end{array}$ \\
\hline 2 & 185 & 23 & $\operatorname{del} A G$ & Stop 39 & $185 \mathrm{delAG}$ & $\mathrm{F}$ & F \\
\hline 5 & 300 & 61 & $\mathrm{~T}$ to $\mathrm{G}$ & Cys to Gly & C61G & M & M \\
\hline 5 & $331+1$ & intron & $\mathrm{G}$ to $\mathrm{A}$ & - & $331+1 \mathrm{G}>\mathrm{A}$ & $S$ & S \\
\hline $11 \mathrm{a}$ & 1135 & 339 & Ins A & Stop 345 & 1135 insA & $\mathrm{F}$ & F \\
\hline $11 \mathrm{a}$ & 1294 & 392 & del40 & Stop 397 & 1294del40 & $\mathrm{F}$ & F \\
\hline $11 b$ & 1675 & 519 & delA & Stop 531 & 1675 delA & $\mathrm{F}$ & $\mathrm{F}$ \\
\hline $11 b$ & 1806 & 563 & $\mathrm{C}$ to $\mathrm{T}$ & Gln to Stop & Q563X & $\mathrm{N}$ & $\mathrm{N}$ \\
\hline $11 b$ & 2457 & 780 & $\mathrm{C}$ to $\mathrm{T}$ & Gln to Stop & Q780X & $\mathrm{N}$ & $\mathrm{N}$ \\
\hline $11 \mathrm{c}$ & 2800 & 894 & $\operatorname{delAA}$ & Stop 901 & 2800delAA & $\mathrm{F}$ & $\mathrm{F}$ \\
\hline $11 \mathrm{c}$ & 2804 & 895 & $\operatorname{delAA}$ & Stop 901 & 2804delAA & $\mathrm{F}$ & $\mathrm{F}$ \\
\hline $11 \mathrm{c}$ & 3166 & 1016 & insTGAGA & Stop 1025 & 3166 ins 5 & $\mathrm{~F}$ & $\mathrm{~F}$ \\
\hline $11 \mathrm{~d}$ & 3600 & 1161 & delGAAGATACTAG & Stop 1163 & 3600del11 & $\mathrm{F}$ & $\mathrm{F}$ \\
\hline $11 \mathrm{~d}$ & 3867 & 1250 & $\mathrm{G}$ to $\mathrm{T}$ & Glu to Stop & E1250X & $\mathrm{N}$ & $\mathrm{N}$ \\
\hline $11 \mathrm{~d}$ & 3875 & 1252 & delGTCT & Stop 1262 & 3875 del 4 & $\mathrm{~F}$ & $\mathrm{~F}$ \\
\hline $11 \mathrm{~d}$ & 4184 & 1355 & delTCAA & Stop 1364 & 4184del4 & $\mathrm{F}$ & F \\
\hline 12 & - & intron & del3835 & - & IVS12-1632del3835 & IVS & UV \\
\hline 13 & 4446 & 1443 & $\mathrm{C}$ to $\mathrm{T}$ & Arg to Stop & R1443X & $\mathrm{N}$ & $\mathrm{N}$ \\
\hline 20 & 5382 & 1756 & insC & Stop 1829 & 5382insC & $\mathrm{F}$ & $\mathrm{F}$ \\
\hline
\end{tabular}

a: Most frequent BRCAl mutations listed in the BIC database

F: Frameshift; M: Missense mutation; N: Nonsense mutation; UV: Unclassified Variant; IVS: Intron Variant Sequence; S: Splicing mutation. 
TABLE III

BRCA1 Primers and Conditions of Mismatch PCR, ASO Hibridization Assay and Restriction Analysis

\begin{tabular}{|c|c|c|c|c|c|}
\hline \multicolumn{6}{|c|}{ A. Mismatch PCR } \\
\hline \multirow[t]{2}{*}{ Mutation } & \multirow[t]{2}{*}{ Forward } & \multirow[t]{2}{*}{ Reverse } & \multirow{2}{*}{$\begin{array}{c}\text { Restriction } \\
\text { Enzime }\end{array}$} & \multicolumn{2}{|c|}{ Size $(b p)^{d}$} \\
\hline & & & & Normal & Mutant \\
\hline 185delAG ${ }^{\mathrm{a}}$ & 5' GAAGTTGTCATTTTATAAACCTTT & 5'TGACTTACCAGATGGGAGAC & Hinf I & $150-20$ & 168 \\
\hline $1675 \mathrm{delA}^{\mathrm{c}}$ & 5' TTCATCCTGAGGATTTTATCTA & 5' CATGAGTTGTAGGTTTCTGCTG & Xba I & $454-19$ & 473 \\
\hline E1250Xc & 5'AGGCATAGCACCGTTGCTTC & ${ }^{5}$ ' TCTTCCAATTCACTGCACTG & Hpy188 I & $167-21$ & 188 \\
\hline $\mathrm{R} 1443 \mathrm{X}^{\mathrm{c}}$ & 5’TTCTGCCCTTGAGGACCCG & 5'ATGTTGGAGCTAGGTCCTTAC & BstUI & $123-19$ & 142 \\
\hline 5382ins $\mathrm{C}^{\mathrm{b}}$ & 5'CCAAAGCGAGCAAGAGAATCTC & 5'GGGAATCCAAATTACACAGC & DdeI & $214-36-20$ & $234-36-20$ \\
\hline \multicolumn{6}{|c|}{$\begin{array}{l}\text { a.Primers and conditions described by Abeliovich et al. (1997) } \\
\text { b.Primers and conditions described by Backe et al. (1998) } \\
\text { c.Primers designed by authors using BRCAl genomic sequence available in Gen Bank (Accession number } \\
\text { L78833) } \\
\text { d.Size of the PCR products after digested with the restriction enzyme. }\end{array}$} \\
\hline \multicolumn{6}{|c|}{ B. Allele Specific Oligonucleotides Hibridization Assaya } \\
\hline Mutation & Normal Oligonucleotides & Mutant Oligonucleotides & & $\begin{array}{c}\text { Tm } \\
\text { oligont }\end{array}$ & $\begin{array}{l}\text { mutant } \\
\text { leotides) }\end{array}$ \\
\hline $331+1 \mathrm{G} \rightarrow \mathrm{A}$ & 5'ATAACCAAAAGGTATATAATTTC & 5'ATAACCAAAAGATATAT & TAATTTGG & & ${ }^{\circ} \mathrm{C}$ \\
\hline 1135insA & 5' CAGCACAGAAAAAAAGG & 5' CAGCACAGAAAAAAAA & & & ${ }^{\circ} \mathrm{C}$ \\
\hline 1294del40 & 5'TGATGAACTGTTAGGT & 5'TGATGAACAAATGCCAA & & & $5^{\circ} \mathrm{C}$ \\
\hline 2800delAA & 5'CCTTAAAGAAACAAAG & 5'CCTTAAAGACAAAGTCC & & & ${ }^{\circ} \mathrm{C}$ \\
\hline 2804delAA & 5'AGAAACAAAGTCCAAA & 5'TAAAGAAACAGTCCAAA & AAGT & & $2^{\circ} \mathrm{C}$ \\
\hline 3166ins5 & 5' ATGAGAACATTCCAAGT & 5' ATGAGATGAGAACATTC & & & $j^{\circ} \mathrm{C}$ \\
\hline 3600del11 & 5' TAAAGGAAGATACTAGTTTTG & 5'GTGAAATAAAGTTTTGC' & TTGA & & $2^{\circ} \mathrm{C}$ \\
\hline 3875del4 & 5'GAGTGTCTGTCTAAGAA & 5'GAGTGTCTAAGAACACA & & & $3^{\circ} \mathrm{C}$ \\
\hline 4184del4 & 5'AGAAAATAATCAAGAAGAG & 5'AGAAAATAAGAAGAGCA & AAAG & & ${ }^{\circ} \mathrm{C}$ \\
\hline
\end{tabular}

a: From Friedman et al. (1994)

C. Restriction Fragments Analysis

\begin{tabular}{lllccc}
\hline Mutation & \multicolumn{1}{c}{ Forward } & Reverse & \multicolumn{2}{c}{$\begin{array}{c}\text { Restriction } \\
\text { Enzime }\end{array}$} & \multicolumn{2}{c}{$\begin{array}{c}\text { Size (bp) } \\
\text { Normal }\end{array}$} \\
& & & Mutant \\
\hline C61G $^{\mathrm{a}}$ & 5' CTCTTAAGGGCAGTTGTGAG & 5'ATGGTTTTATAGGAACGCTATG & HpyCH4 III & 154-74-50 & $228-50$ \\
Q563X $^{\text {b }}$ & 5' ATGATAAATCAGGGAACTAACC & 5' CATGAGTTGTAGGTTTCTGCTG & Hpy188 I & $320-98$ & 418 \\
Q780X $^{\text {a }}$ & 5'CACCTAAAAGAATAGGCTGAG & 5' AGTAATGAGTCCAGTTTCGTTG & Hpy188 III & 525-380-183 & 708-380 \\
\hline
\end{tabular}

a: From Friedman et al. (1994)

b: Primers designed by authors using BRCAl genomic sequence available in Gen Bank (Accession number L78833)

c: Size of the fragments after restriction enzyme assay 
Allele-specific oligonucleotide (ASO) hybridization assay

The BRCA1 331+1G $\rightarrow$ A (Exon 5), 1135insA (Exon 11a), 1294del40 (Exon 11a), 2800delAA (Exon 11c), 2804delAA (Exon 11c), 3166ins5 (Exon 11c), 3600del11 (Exon 11d), 3875del4 (Exon 11d) and 4184del4 (Exon 11d) mutations were identified by ASO hybridization assay using the conditions previously described by Friedman et al., (1995). Ten picomoles of oligonucleotides specific to each mutation and its wild-type sequence were 3'-end labeling with digoxigenin-11-ddUTP using a digoxigenin-oligonucleotide-labeling kit (Roche Applied Science) according to manufacturer's instructions. ASOs for known mutations are given in Table IIIB. Dot blot filters carrying amplified DNA were pre-hybridized with $20 \mathrm{ml} / 100 \mathrm{~cm}^{2}$ of pre-hybridization buffer $5 \mathrm{x}$ SSC (1xSSC: $0.15 \mathrm{M} \mathrm{NaCl}$ and $0.015 \mathrm{M}$ Na-citrate, $\mathrm{pH}$ 7.0), $1 \%$ of casein, $0.1 \%$ N-laurylsarcosine, and $0.02 \%$ SDS at $5-10^{\circ} \mathrm{C}$ below oligonucleotide-melting temperature (Th) for at least 1 hour and hybridized overnight with $20 \mathrm{ml}$ of hybridization buffer (prehybridization buffer with non-isotopic oligonucleotide) at the same temperature (Th). The filters were washed twice with 20 $\mathrm{ml}$ of $0.3 \mathrm{M} \mathrm{NaCl}, 30 \mathrm{mM}$ Na Citrate, $\mathrm{pH} 7.0$ for $5 \mathrm{~min}$ at room temperature and twice with $75 \mathrm{mM} \mathrm{NaCl}, 7.5 \mathrm{mM} \mathrm{Na}$ Citrate $\mathrm{pH}$ 7.0 for $15 \mathrm{~min}$ at room temperature. The filters were manipulated exclusively with tweezers and were not allowed to dry following the hybridization step.

\section{Chemiluminescent detection}

The filters were washed with $20 \mathrm{ml}$ of buffer $1(100 \mathrm{mM}$ Maleic acid, $150 \mathrm{mM}$ $\mathrm{NaCl}, 0.3 \%$ Tween 20, $\mathrm{pH}$ 7.5) for one min at room temperature. It was then transferred to a new recipient and incubated with $20 \mathrm{ml}$ of Buffer 2 (Buffer 1 with $1 \%$ (w/v) casein) for $30 \mathrm{~min}$ at room temperature. The anti-digoxigenin antibody (Roche Applied Science) was diluted $1: 10,000$ in $20 \mathrm{ml}$ of Buffer 2 five min before the end of the incubation with Buffer 2. Following incubation for $30 \mathrm{~min}$, Buffer 2 was replaced by the diluted antibody solution, and the filter was left for $30 \mathrm{~min}$ at room temperature. The antibody solution was then removed and the membrane washed with $20 \mathrm{ml}$ of Buffer 1 . The filter was transferred to a new recipient and incubated with $20 \mathrm{ml}$ of Buffer 1 containing $0.3 \%$ Tween 20 for $15 \mathrm{~min}$ at room temperature. Buffer 1 was then replaced by $20 \mathrm{ml}$ of Buffer 3 (100 mM Tris- $\mathrm{HCl}, \mathrm{pH}$ 9.5, 100 $\mathrm{mM} \mathrm{NaCl}$ ) and incubated for $5 \mathrm{~min}$ at room temperature. The filter was placed between two cellulose acetate sheets, and $0.5 \mathrm{ml} / 100$ $\mathrm{cm} 2$ of CSPD diluted 1:100 in Buffer 3 was added to the filter, between the acetate sheets. After careful removal of the air bubbles, the acetate sheets were heat sealed, and the filter was incubated for $15 \mathrm{~min}$ at $37^{\circ} \mathrm{C}$. Finally, the filter was exposed on Kodak X-OMAT ray film for $2 \mathrm{~h}$.

\section{Restriction Fragments Analysis}

The BRCA1 C61G (Exon 5), Q563X (Exon $11 \mathrm{~b}$ ) and Q780X (Exon 11b) mutations were identified by restriction fragment analysis. Genomic DNA of breast cancer probands was amplified by PCR assay, using primers given in Table IIIC and the conditions previously described in the section mismatch PCR assay. The PCR products were digested with a restriction enzyme (Table IIIC) using the conditions described by suppliers (New England Biolabs) and the products were resolved on agarose gels. Table IIIC shows the size of the normal and mutant alleles after restriction enzyme assay.

\section{Allele specific PCR assay}

The IVS12-1643del3835 mutation was identified by allele specific PCR assay. The reaction contained $1.5 \mathrm{mM} \mathrm{MgCl}_{2}, 400 \mathrm{nM}$ primer $12 \mathrm{~F}$ ( 5 , TTCTTCAGCACCCCGT TC CA), $400 \mathrm{nM}$ of the deletion specific primer 12Fdel3835 (5' CAATGTGTTCC TGCCCTACT), and $800 \mathrm{nM}$ primer 12R (5' ACACTGGAAGACAACAGATATTAA). PCR conditions were $95^{\circ} \mathrm{C}$ for $5 \mathrm{~min},\left(94^{\circ}\right.$ for $1 \mathrm{~min}, 60^{\circ} \mathrm{C}$ for $1 \mathrm{~min}$, and $72^{\circ} \mathrm{C}$ for 1 $\min$ ) for 30 cycles, and $72^{\circ} \mathrm{C}$ for $10 \mathrm{~min}$. The reactions were resolved on $1.5 \%$ 
agarose gels, producing a single band of $1243 \mathrm{bp}$ among normal individuals and both $1343 \mathrm{bp}$ and $500 \mathrm{bp}$ in individuals who are heterozygous or homozygous for the IVS12-1643del3835 mutation.

\section{Direct sequencing}

All the mutants, unknown significance variants, and polymorphisms found were sequenced in the probands and in the healthy relatives to verify the sequence variants. The DNA isolated from mutant allele carriers was amplified by PCR and the products purified using and ENZA Cycle- pure kit (Labclinic). The purified DNA was subjected to cycle sequencing using an automated fluorescence-based cycle sequencer (ABI Prism 3100, PerkinElmer) and dye terminator system.

\section{Human Subjects}

All the individuals that agreed to participate in the study signed a written informed consent form. The study was approved by the University of Chile, School of Medicine Review Board.

\section{RESULTS}

We have studied 70 probands and 98 healthy relatives of 63 breast and/or ovarian families to screen 18 frequent mutations in five exons $(2,5,11,13$ and 20) and two introns (5 and
12) in the breast/ovarian cancer susceptibility gene $B R C A 1$. Two BRCAl frequent mutations and one variant of uncertain significance (BIC) were found in four of the families. Also, one new mutation and one polymorphism previously described (BIC) were found in two other families (Table IV).

In two families of the cohort $(3.17 \%)$ (families F4 and F46), the identified mutation was 185 delAG in exon 2 , which is the most common alteration reported in BRCAl (Shattuck-Eidens et al., 1995; Simard et al., 1994; Struewing et al., 1995). The reported families segregating this mutation are usually of Ashkenazi Jewish origin (Tonin et al., 1995). Families F4 and F46 did not self-report any Ashkenazi ancestors. Family F4 (Fig 1A) presented two cases of women affected with breast cancer at ages 62 (II-3) and 38 (III-3), one case of uterine cancer and one case of prostate cancer. The $185 \mathrm{del}$ AG mutation was detected in the proband and in her healthy sister, who is now 48 years old. Family F46 (Fig 1B) contained three cases of women with breast cancer at ages 80 (III-6), 70 (III-10), and 42 (IV-2), three cases of ovarian cancer and five more cases affected with other cancers (Fig. 1B, Table IV). The mutation was found in the proband and in her healthy 18 year-old-niece (V-1). The mother of V-I died of ovarian cancer when she was 34 years old, and she was probably a carrier of $185 \mathrm{del}$ AG mutation or other breast-ovarian cancer susceptibility mutation.

TABLE IV

Germline BRCA1 mutations

\begin{tabular}{|c|c|c|c|c|c|c|c|c|c|}
\hline Family & Female & Average & Ovarian & Average & Male & Cancer at & BRCA1 & Exon & Effect \\
\hline $\mathrm{F} 4$ & 2 & 50 & - & - & 0 & Prost, Ut & 185 delAG & 2 & Stop 39 \\
\hline F46 & 3 & 64 & 3 & 43.3 & 0 & Pan, Test, Co, Melan & 185delAG & 2 & Stop 39 \\
\hline F13 & 4 & 40.25 & - & - & 0 & Prost, St, Kid, Lu, Bo & C61G & 5 & Cys to Gly \\
\hline F14 & 3 & 38 & - & - & 0 & $\mathrm{Ut}, \mathrm{St}$ & $\mathrm{E} 1250 \mathrm{~K}$ & 11 & Glu to Lys \\
\hline F21 & 3 & 47 & - & - & 0 & - & 4185 del 4 & 11 & Stop 1364 \\
\hline F25 & 3 & 45.6 & - & - & 0 & Ut, Pan, St, Melan & E1038G & 11 & Polymorphism \\
\hline
\end{tabular}

F: Family; Prost: Prostate cancer; Ut: Uterine cancer; Co: Colon cancer; Pan: Pancreatic cancer; Melan: Melanoma; Test: Testicular cancer; St: Stomach cancer; Kid: Kidney cancer; Lu: Lung cancer; Bo: Bone cancer. * Average age of female breast cancer cases per family; ** Average age of ovarian cancer cases per family. 
$\mathbf{A}$

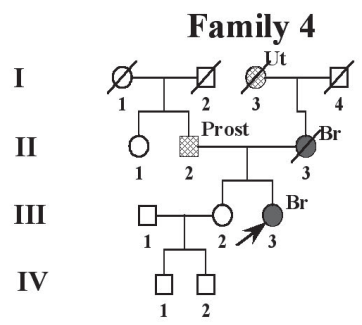

185delAG mutation

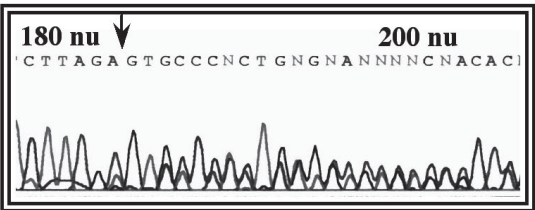

C

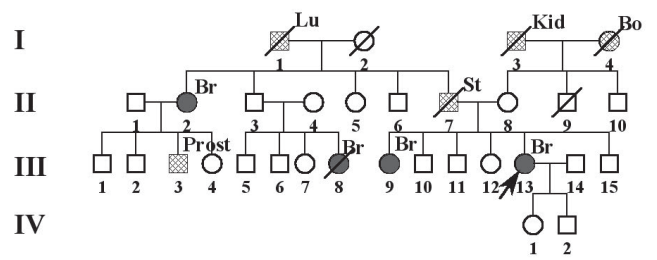

C61G mutation

\begin{tabular}{|c|}
\hline \\
\hline 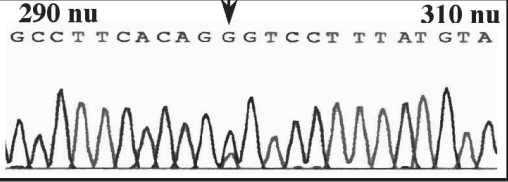 \\
\hline
\end{tabular}

E

Family 21

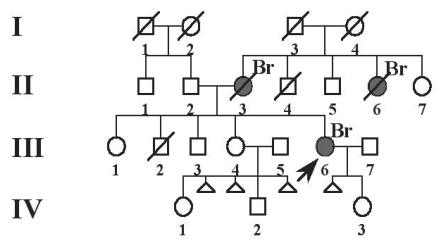

4185delCAAG mutation

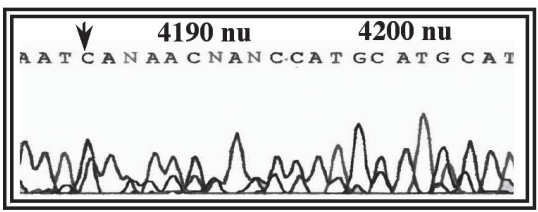

B I

Family 46

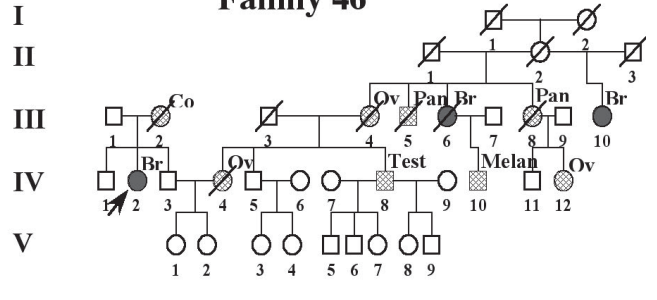

185delAG mutation

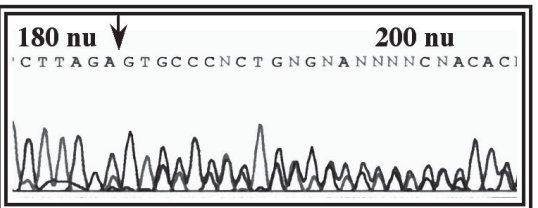

D

Family 14

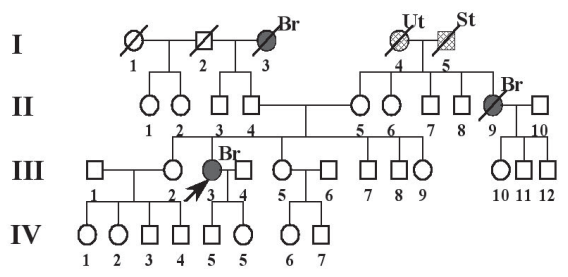

E1250K mutation

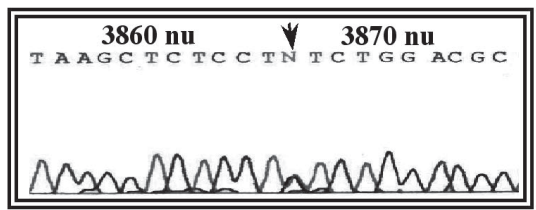

F

Family 25

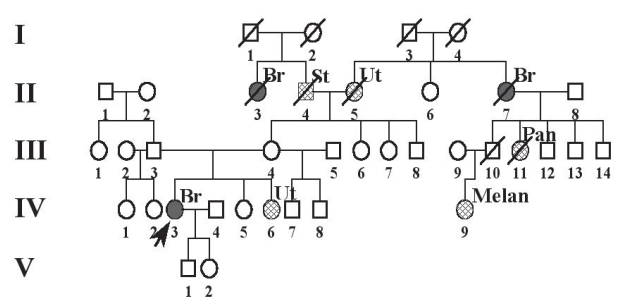

E1250G polymorphism

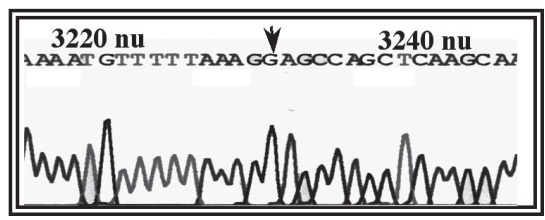

Figure 1: Pedigrees of families F4 (A), F46 (B), F13 (C), F14 (D), F21 (E) and F25 (F). Lower panel, electropherograms showing the mutations that were found in the families. F: Family; Br: Breast cancer; Ov: Ovarian cancer; Prost: Prostate cancer; Ut: Uterine cancer; Co: Colon cancer; Pan: Pancreatic cancer; Melan: Melanoma; Test: Testicular cancer; St: Stomach cancer; Kid: Kidney cancer; Lu: Lung cancer; Bo: Bone Cancer; nu: nucleotide 
Another frequent mutation was C61G in exon 5. This mutation was found in only one family studied, (F13) (1.59\%). Family F13 (fig. 1C) contained four cases of female breast cancer at ages 50 (II-2), 37 (III-8), 37 (III-9) and 37 (III-13), one case of prostate cancer, and four cases with other cancers (Table IV). In this family we obtained DNA samples from the following women III-7, III-12, and III-13. The mutation was detected in the proband and in her healthy sister (III-12) (Fig 1c), but it was not found in her healthy cousin (III-7).

Unexpectedly during the screening for E1250X mutation, we identified the E1250K variant, given the technique used allows the detection of any change of $G$ base. The E1250K variant, previously reported although of unknown significance, corresponds to a change of $G$ to $A$ in nucleotide 3867 in exon 11. This variant was found in family F14 (Fig. 1D). This family contained three cases of female breast cancer at ages 36 (I-3), 30 (II-9), and 47 (III-4), one case of stomach cancer and one case of uterine cancer. This variant was studied in the proband (III-4) and in five healthy relatives (II-5, II-6, III-2, III-5 and III-10). This missense mutation was only found in the mother (68 years) (II-5) and in the sister (50 years) (III-2) of the proband, neither of whom were affected with breast and/or ovarian cancer. The proband (47 years) of this family does not present the aforementioned variant.

The new mutation detected is a four base pair deletion of CAAG in nucleotide 4185 in exon 11 and its leads to a premature termination at codon 1364. This mutation was identified during the screening for 4184 del 4 by direct sequencing. The 4185 del 4 mutation was found in family F21 (Fig. 1E) which presented three cases of breast cancer at ages of 47 (II-3), 45 (II-6), and 49 (III-6). We obtained DNA samples only from III-4 and III-6 individuals. The mutation was found in the index case (III-6) but not in her healthy sister (III-4). Sequencing of the amplified DNA revealed heterozygosity for the 4185 del 4 mutation in the proband and the presence of normal alleles in her healthy sister. To our knowledge, this mutation has not been previously described and is not included in the BIC database.

A polymorphic variant previously reported was detected in family F25 (Fig. $1 \mathrm{~F}$ ) during the screening of the 3166 ins 5 by direct sequencing. This polymorphism corresponds to a change of $\mathrm{A} \rightarrow \mathrm{G}$ at 3232 nucleotide in exon 11. This family presented three cases of female breast cancer at ages 46 (II-3), 55 (II-7), and 36 (IV-3), two cases of uterine cancer, and three cases with other cancers (Table IV). In this family we obtained a DNA sample only from the proband. The proband (IV-3) with breast cancer was homozygote for the sequence variant.

\section{DISCUSSION}

Germ-line mutations in the BRCAl and $B R C A 2$ genes account for the majority of high-risk breast/ovarian cancer families, depending on the population studied. The BIC database list has recorded the most frequent disease-associated mutations. In this study we analyzed eighteen frequent mutations located in five exons and two introns in the BRCAl gene, in 63 Chilean families with breast/ovarian cancer history. BRCA1 mutations were found in five of our families $(7.93 \%)$ but only three of them $(4.76 \%)$ had two of the eighteen mutations studied.

The 185 delAG was the first mutation detected with a high frequency in Ashkenazi Jews (Friedman et al., 1995; Struewing et al., 1995). Recent epidemiological studies have detected the $185 \mathrm{delAG}$ mutation in non-Jewish individuals in populations of other countries (Bar-Sade et al., 1998), including non-Jewish origin Spanish (Osorio et al., 1998; Díez et al., 1998; Díez et al., 1999). Trincado et al., (1999), did not detect the 185 delAG mutation in 55 Chilean women affected with breast cancer, 15 of whom had a positive family history and 40 with sporadic breast cancer. The study of Jara et al., (2002) was the first to establish a frequency of $0.26 \%$ for the $185 \mathrm{delAG}$ mutation in a group of 382 healthy Chilean women with at least two relatives with breast cancer. In the present study two families 
were carriers of the $185 \mathrm{delAG}$ mutation, and individuals of these families reported no Jewish ancestors. Recently Ah Mew et al., (2002) identified the 185 delAG mutation in a non-Jewish Chilean family. Therefore, the existence of this mutation in the current admixed Chilean population may have been brought by the Spanish settlers. Nevertheless this mutation has not yet been studied in the remnants of the few Amerindians that still remain geographically isolated in some regions of the country.

The second mutation detected was the C61G (exon 5) present in only one of the 63 families. This mutation has been described in Poland (Jakubowska et al., 2001, van Der Looij et al., 2000a), Hungary (van Der Looij et al., 2000b), Germany (Spitzer et al., 2000), and in other regions of Europe (BIC), although it is not a recurrent mutation in the Spanish population. The affected family with the C61G mutation had no recent European ancestry, the maternal lineage having only Chilean ancestry dating back several generations. The paternal lineage is Jewish Ashkenazi dating back two generations; however, the C61G mutation is not frequent in Jewish populations. There is a history of cancer in both familial lineages, although breast cancer is present only in the paternal lineage. A possible explanation for this finding could be the admixture of the Jewish ancestors of this family with Europeans where this mutation is frequent.

The third sequence variant found in our sample was in exon 11d and consisted of a change of $\mathrm{G}$ to $\mathrm{A}$ in nucleotide 3867 , which causes a change of an acidic amino acid (glutamic acid) for a basic one (lysine). This missense mutation, designated E1250K, has been classified as a variant of unknown significance (BIC). The E1250K has been reported at least eight times, and five of the records correspond to Western Europe (BIC). It has also been described in Spanish populations (Díez et al., 2003) and is absent in different series of healthy controls. This variant was detected in only one of our 63 families. In this family breast cancer was diagnosed at an early age in the three cases. Therefore, it is more probable that this family presents hereditary breast cancer rather than sporadic breast cancer. The unknown significance variant was not present in the proband, but it was in the two healthy relatives; therefore this family did not allow us to establish the variant significance. A probable explanation could be that in this family another diseaseassociated mutation is present to account for hereditary breast cancer. The presence of this variant in the Chilean population could represent a founder effect of Spanish origin.

In family $\mathrm{F} 21$, a four base pair deletion of CAAG in nucleotide 4185 was detected. This frameshift mutation is predicted to result in a protein truncation at codon 1364 , putatively deleting $27 \%$ of the protein. Mutation 4185del4 differs from the previously described 4184delTCAA (BIC), which corresponds to a deletion of $4 \mathrm{bp}$ in nucleotide 4184. Nevertheless these two mutations produce the same effect, given that both generate a stop codon 1364 . Therefore the only difference between them is that in our case, the deletion occurs one base pair after the 4184 del 4 mutation. To our knowledge, this mutation has not been previously described. In family F21 all the breast cancer cases were diagnosed prior to age 50. Therefore the 4185 del 4 mutation has high penetrance and it may explain the breast cancer in this family. One of the healthy sisters of the proband (III-4) had normal alleles. We could not obtain DNA from the proband's other healthy sister, however, since she is now 74 years old, she probably has normal alleles.

Our last finding corresponds to a polymorphic variant in the nucleotide 3232 designated E1038G (BIC). This polymorphism has been described in Germany, Italy, USA, Sweden, Greece, and in the Spanish population (BIC). It has also been described in Chinese Malaysians and Brazil (BIC). The highest number of records in BIC database corresponds to cases in the Spanish population. It is therefore likely that the presence of this polymorphism in the Chilean population also represents a founder effect of Spanish origin.

Since the present Chilean population stems from the admixture of Amerindian (Mongoloids) and the Spanish (Caucasians), 
some of the mutations associated with hereditary breast cancer in Chileans may be the same mutations that were present in the ancestors. Other, new mutations may be generated following the Amerindian and Spanish admixture, which have still not been described. The results of the present study show that four of the sequence variants detected in Chilean breast cancer families correspond to previously described variants and one corresponds to a new mutation with no BIC record. However, none of the mutations detected showed a high frequency in the group of families studied.

The identification of BRCA1 mutations could facilitate the setting up of a methodological strategy that could be less expensive and less time-consuming for the BRCA1 mutation detection in Chileans.

\section{ACKNOWLEDGEMENTS}

This research was funded by Avon Breast Cancer Crusade-CONAC and Fondecyt 1010800 .

\section{REFERENCES}

ABELIOVICH D, KADURI L, LERER I., WEIBERG N, AMIR G., SAGI M, ZLOTOGORA J, HECHING N, PERETZ T (1997) The founder mutations 185delAG and 5382insC in BRCAl and 6174delT in BRCA2 appear in $60 \%$ of ovarian cancer and $30 \%$ of early onset breast cancer patients among Ashkenazi women. Am J Hum Genet 60: 505-514

AH MEW N, HAMEL N, GÁLVEZ M, AL-SAFFAR M, FOULKES WD (2002) Haplotype analysis of a BRCA1: 185delAG mutation in a Chilean family supports its Ashkenazi origins. Clin Genet 62: 151-156

BACKE J, HOFFERBERT S, SKAWRAN B, DORK T, STUHRMANN M, KARSTENS JH, UNTCH M, MEINDL A, BURGEMEISTER R, CHANG-CLAUDE J, WEBER BH (1999) Frequency of BRCAl mutation 5382insC in German breast cancer. Gynecol Oncol 72: 402-406

BAR-SADE RB, KRUGLIKOVA A, MODAN B, GAK E, HIRSH-YECHEZKEL G, THEODOR L, NOVIKOV I, GERSHONI-BARUCH R, RISEL S, PAPA MZ, BENBARUCH G, FRIEDMAN E (1998) The 185delAG $B R C A 1$ mutation originated before the dispersion of Jews in the Diaspora and is not limited to Ashkenazim. Hum Mol Genet 7: 801-805

BORG A, DORUM A, HEIMDAL K, MAEHLE L, HOVIG E, MOLLER P (1999) BRCAl 1675delA and 1135 ins A account for one third of Norwegian familial breast-ovarian cancer and are associated with later disease onset than less frequent mutations. Dis Markers 15: 19-84
BREAST CANCER INFORMATION CORE-DATABASE (BIC) http://www.nhgri.nih.gov/Intramural_research/ Lab_tranfer/Bic/ http://www.ncbi.nlm.nih.gov/Genbank

CHOMCZYNSKY P, SACCHI N (1987) Single step method of RNA isolation by guanidium thiocyanatephenol-cloroform extraction. Anal Biochem 162: 156-158

CLAES K, MACHACKOVA E, DE VOS M, POPPE B, DE PAEPE A, MESSIAEN L (1999) Mutation analysis of the BRCA1 and BRCA2 genes in the Belgian patient population and identification of a Belgian founder mutation BRCAl IVS5+3 A>G. Dis Markers 15: 69-73

CRUZ-COKE R (1976) Origen y evolución étnica de la población chilena. Rev Med Chile 101: 365-368

DE SANJOSE S, LEONE M, BEREZ V, IZQUIERDO A, FONT R, BRUNET JM, LOUAT T, VILARDELL L, BORRAS J, VILADIU P, BOSCH FX, LENOIR GM, SINILNIKOVA OM (2003) Prevalence of BRCA1 and $B R C A 2$ germline mutations in young breast cancer patients: a population-based study. Int J Cancer 106: 588-593

DIEZ O, DOMENECH M, ALONSO MC, BRUNET J, SANZ J CORTÉS J, DEL RÍO E, BAIGET M (1998) Identification of the 185 delAG BRCAl mutation in a Spanish Gypsy population. Hum Genet 103: 707-708

DIEZ O, OSORIO A, ROBLEDO M, BARROSO A, DOMENECH M, CORTÉS J, ALBERTOS J, SANZ J, BRUNET J, SAN RAMÓN JM, ALONSO MC, BAIGET M, BENÍTEZ J (1999) Prevalence of BRCAl and $B R C A 2$ Jewish mutations in Spanish breast cancer patients. Br J Cancer 79: 1302-1303

DIEZ O, OSORIO A, DURÁN M, MARTÍNEZFERRANDIS JI, HOYA MD MDE L, SALAZAR R, VEGA A, CAMPOS B, RODRÍGUEZ-LÓPEZ R, VELASCO E, CHAVES J, DÍAZ-RUBIO E, JESÚS CRUZ J, TORRES M, ESTEBAN E, CERVANTES A, ALONSO C, SAN ROMÁN JM, GONZÁLEZSARMIENTO R, MINER C, CARRACEDO A, EUGENIA ARMENGOD M, CALDES T, BENÍTEZ J, BAIGET M (2003) Analysis of BRCAl and BRCA2 genes in Spanish breast/ovarian cancer patients: A high proportion of mutations unique to Spain and evidence of founder effects. Hum Mutat 22: 301-312

DURÁN M, ESTEBAN-CARDENOSA E, VELASCO E, INFANTE M, MINER C (2003) Mutational analysis of BRCA2 in Spanish breast cancer patients from Castilla-Leon: identification of four novel truncating mutations. Hum Mutat 21: 448

ENCINA F (1983): Historia de Chile, Vol I. Santiago de Chile: Ercilla. pp: 51-59

FORD D, EASTON DF, STRATTON M, NAROD S, GOLDGAR D, DEVILEE P, BISHOP DT, WEBER B, LENOIR G, CHANG-CLAUDE J, SOBOL H, TEARE MD, STRUEWING J, ARASON A, SCHERNECK S, PETO J, REBBECK TR, TONIN P, NEUHAUSEN S, BARKARDOTTIR R, EYFJORD J, LYNCH H, PONDER BA, GAYTHER SA, BIRCH JM, LINDBLOM A, STOPPA-LYONNET D, BIGNON Y, BORG A, HAMANN U, HAITES N, SCOTT RJ, MAUGARD CM, VASEN H, SEITZ SA, CANNON-ALBRIGHT L, SCHOFIELD A, ZELADA-HEDMAN M. THE BREAST CANCER LINKAGE CONSORTIUM (1998) Genetic heterogeneity and penetrance analysis of the BRCAl and $B R C A 2$ genes in breast cancer families. Am J Hum Genet 62: 676-689

FRIEDMAN LS, OSTERMEYER EA, SZABO CI, DOWD P, LYNCH ED, ROWELL SE, KING MC (1994) Confirmation of $B R C A l$ by analysis of germline mutations linked to breast and ovarian cancer in ten families. Nat Genet 8: 399-404 
FRIEDMAN LS, SZABO CI, OSTERMEYER EA, DOWD P, BUTLER L, PARK T, LEE MK, GOODE EL, ROWELL SE, KING MC (1995) Novel inherited mutations and variable expressivity of $B R C A 1$ alleles, including the founder mutation 185delAG in Ashkenazi Jewish families. Am J Hum Genet 57: 284-297

GAYTHER SA, WARREN W, MAZOYER S, RUSSELL PA, HARRINGTON PA, CHIANO M, SEAL S, HAMOUDI R, VAN RENSBURG EJ, DUNNING AM, LOVE R, EVANS G, EASTON D, CLAYTON D, STRATTON MR, PONDER BAJ (1995) Germline mutations of the BRCA1 gene in breast and ovarian cancer provide evidence for a genotype-phenotype correlation. Nat Genet 11: 428-433

INOUE R, FUKUTOMI T, USHIJIMA T, MATSUMOTO Y, SUGIMURA T, NAGAO M (1995) Germline mutation of BRCAl in Japanese breast cancer. Cancer Res 55: 3521-3524

INSTITUTO NACIONAL DE ESTADÍSTICAS (INE): http://www.ine.cl http://www.ncbi.nlm.nih.gov/entrez/ queryfcgi? db=OMIN

JAKUBOWSKA A, GORSKI B, BYRSKI T, HUZARSKI T, GRONWALD J, MENKISZAK J, CYBULSKI C, DEBNIAK T, HADACZEK P, SCOTT RJ, LUBINSKI $\mathrm{J}$ (2001) Detection of germline mutations in the BRCAI gene by RNA-based sequencing. Hum Mutat 18: 149156

JARA L, AMPUERO S, SECCIA L, BUSTAMANTE M, BLANCO R, SANTIBÁÑEZ E, REYES JM, OJEDA JM (2002) Frecuencia de la mutación 185delAG en el gen $B R C A l$ en mujeres chilenas sanas con antecedentes familiares de cáncer de mama. Rev med Chile 130: 1113-1123

JOHANNSSON O, OSTERMEYER EA, HAKANSSON S, FRIEDMAN LS, JOHANSSON U, SELLBERG G, BRONDUM-NIELSEN K, SELE V, OLSSON H, KING MC, BORG A (1996) Founding BRCAl mutations in hereditary breast and ovarian cancer in southern Sweden. Am J Hum Genet 58: 441-450

KATAGIRI T, EMI M, ITO I, KOBAYASHI K, YOSHIMOTO M, IWASE T, KASUMI F, MIKI Y, SKOLNICK MH, NAKAMURA Y (1996). Mutations in the BRCA1 gene in Japanese breast cancer patients. Hum Mutat 7: 334-339

LI SS, TSENG HM, YANG TP, LIU CH, TENG SJ, HUANG HW, CHEN LM, KAO HW, CHEN JH, TSENG JN, CHEN A, HOU MF, HUANG TJ, CHANG HT, MOK KT, TSAI JH (1999) Molecular characterization germline mutations in the BRCAl and BRCA2 genes from breast cancer families in Taiwan. Hum Genet 104: 201-204

LLORT G, MUNOZ CY, TUSER MP, GUILLERMO IB, LLUCH JR, BALE AE, FRANCO MA (2002) Low frequency of recurrent $B R C A 1$ and $B R C A 2$ mutations in Spain. Hum Mutat 19: 307

LYNCH HT (1981) Genetics and Breast Cancer. New York: Van Nostrand Kheinhold

MALONE KE, DALING JR, THOMPSON JD, OBRIEN CA, FRANCISCO LV, OSTRANDER EA (1998) $B R C A 1$ mutations and breast cancer in the general populations analyses in women before age 35 years and in women before age 45 years with first-degree family history. JAMA 279: 922-929

MANGUOGLU AE, LULECI G, OZCELIK T, COLAK T, SCHAYEK H, AKAYDIN M, FRIEDMAN E (2003) Germline mutations in the $B R C A 1$ and $B R C A 2$ genes in Turkish breast/ovarian cancer patients. Hum Mutat 21: 444-445

MATSUSHIMA M, KOBAYASHI K, EMI M, SAITO H, SAITO J, SUZUMORI K, NAKAMURA Y (1995)
Mutation analysis of the BRCAl gene in 76 Japanese ovarian cancer patients: four germline mutations, but no evidence of somatic mutation. Hum Mol Genet 4: 1953-1956

MIKI Y, KATAGIRI T, KASUMI F, YOSHIMOTO T, NAKAMURAY (1996) Mutation analysis in the BRCA2 gene in primary breast cancers. Nat Genet 13: 245-247

NATHANSON KL, WOOSTER R, WEBER BL, NATHANSON KN (2001) Breast cancer genetics: what we know and what we need. Nat Med 7: 552-556

NEUHAUSEN SL (2000) Founder populations and their uses for breast cancer genetics. Breast Cancer Res 2: $77-81$

OSORIO A, ROBLEDO M, ALBERTOS J, DIEZ O, ALONSO C, BAIGET M, BENÍTEZ J (1998) Molecular analysis of the six most recurrent mutations in the $B R C A 1$ gene in 87 Spanish breast/ovarian cancer families. Cancer Lett 123: 153-158

OSORIO A, BARROSO A, MARTÍNEZ B, CEBRIAN A, SAN ROMÁN JM, LOBO F, ROBLEDO M, BENÍTEZ $\mathrm{J}$ (2000) Molecular analysis of the BRCA1 and BRCA2 genes in 32 breast and/or ovarian cancer Spanish families. Br J Cancer 82: 1266-1270

PALOMINO HM, PALOMINO H, CAUVI D (1990) Variación socio-genética en la susceptibilidad a las fisuras faciales en Santiago, Chile. Odont Chil 38: 86-92

PALOMINO H, LI SC, PALOMINO HM, BARTON SA, CHAKROBORTYU R (1991) Complex segregation analysis of facial clefting in Chile. Am J Hum Genet (suppl) 49: 154

PANGULURI RC, BRODY LC, MODALI R, UTLEY K, ADAMS-CAMPBELL L, DAY AA, WHITFIELDBROOME C, DUNSTON GM (1999) BRCAl mutations in African Americans. Hum genet 105: 28-31

PARKIN DM (1994) Cancer in developing countries Cancer Surv 20: 519-561

PEELEN T, VAN VLIET M, PETRIJ-BOSCH A, MIEREMET R, SZABO C, VAN DEN OUWELAND AMW, HOGERVORST F, BROHET R, LIGTENBERG MJL, TEUGELS E, VAN DER LUIJT R, VAN DER HOUT AH, GILLE JJP, PALS G, JEDEMA I, OLMER R, VAN LEEUWEN I, NEWMAN B, PLANDSOEN M, VAN DER EST M, BRINK G, HAGEMAN S, ARTS PJW, BAKKER MM, WILLEMS HW, VAN DER LOOIJ E, NEYNS B, BONDUELLE M, JANSEN $\mathrm{R}$, OOSTERWIJK JC, SIJMONS R, SMEETS HJM, VAN ASPEREN CJ, MEIJERS-HEIJBOER H, KLIJN JGM, DE GREVE J, KING MC, MENKO FH, BRUNNER HG, HALLEY D, VAN OMMEN GJB, VASEN HFA, CORNELISSE CJ, VAN T VEER LJ, DE KNIJFF P, BAKKER E, DEVILEE P (1997) A High Proportion of Novel Mutations in BRCAl with Strong Founder Effects among Dutch and Belgian Hereditary Breast and Ovarian Cancer Families. Am J Hum Genet 60: 1013-1020

PERALTA O, JORQUERA A, RENCORET C, CASTILLO CD, SOLÉ J, CAMPODÓNICO Y (1995) Cáncer de Mama, Resultados del Programa de Pesquisa y Tratamiento del Servicio de Salud Central. Rev Chil Obstet Ginecol 60: 417

RUIZ-FLORES P, SINILNIKOVA OM, BADZIOCH M, CALDERÓN-GARCIDUENAS AL, CHOPIN S, FABRICE O, GONZÁLEZ-GUERRERO JF, SZABO C, LENOIR G, GOLDGAR DE, BARRERASALDANA HA (2002) BRCA1 and BRCA2 mutation analysis of early-onset and familial breast cancer cases in Mexico. Hum Mutat. 20: 474-475

SAXENA S, SZABO CI, CHOPIN S, BARJHOUX L, SINILNIKOVA O, LENOIR G, GOLDGAR DE, 
BHATANAGER D (2002) BRCA1 and BRCA2 in Indian breast cancer patients. Hum Mutat 20: 473-474

SCHUBERT EL, LEE MK, MEFFORD HC, ARGONZA RH, MORROW JE, HULL J, DANN JL, KING MC (1997) BRCA2 in American families with four or more cases of breast or ovarian cancer: recurrent and novel mutations, variable expression, penetrance, and the possibility of families not attributable to BRCAl or BRCA2. Am J Hum Genet 60: 1031-1040

SEROVA OM, MAZOYER S, PUGET N, DUBOIS V, TONIN P, SHUGART YY, GOLDGAR D, NAROD SA, LYNCH HT, LENOIR (1997) Mutations in BRCA1 and $B R C A 2$ in breast cancer families: are there more breast cancer-susceptibility genes? Am J Hum Genet 60: 486-495

SHATTUCK-EIDENS D, MCCLURE M, SIMARD J, LABRIE F, NAROD S, COUCH F, HOSKINS K, WEBER B, CASTILLA L, ERDOS M, BRODY L, FRIEDMAN L, OSTERMEYER E, SZABO C, KING MC, JHANWAR S, OFFIT K, NORTON L, GILEWSKI T, LUBIN M, OSBORNE M, BLACK D, BOYD $M$, STEEL $M$, INGLES S, HAILE $R$, LINDBLOM A, OLSSON H, BORG A, BISHOP DT, SOLOMON E, RADICE P, SPATTI G, GAYTHER S, PONDER B, WARREN W, STRATTON M, LIU Q, FUJIMURA F, LEWIS C, SKOLNICK MH, GOLDGAR DE (1995) A collaborative survey of 80 mutations in the BRCAl breast and ovarian cancer susceptibility gene. JAMA 273: 535-541

SIMARD J, TONIN P, DUROCHER F, MORGAN K, ROMMENS J, GINGRAS S, SAMSON C, LEBLANC JF, BELANGER C, DION F, LIU Q, SKOLNICK M, GOLDGAR D, SHATTUCK-EIDENS D, F LABRIE, SA NAROD (1994) Common origin of BRCAl mutations in Canadian breast and ovarian cancer families. Nat Genet 8: 392-398

SPITZER E, ABBASZADEGAN MR, SCHMIDT F, HAUSER A, BUWITT U, LAUTER FR, POTSCHICK K, KROCKER J, ELLING D, GROSSE R. (2000) Detection of BRCAI and BRCA2 mutations in breast cancer families by a comprehensive two-stage screening procedure. Int J Cancer 85: 474-481.

STRUEWING JP, ABELIOVICH D, PERETZ T, AVISHAI N, KABACK MM, COLLINS FS, BRODY, LC (1995)
The carrier frequency of the BRCA1 $185 \mathrm{delAG}$ mutation is approximately 1 percent in Ashkenazi Jewish individuals. Nat Genet 11 198-200

SZABO CI, KING MC (1997) Population genetics of BRCA1 and BRCA2. Am J Hum Genet 60: 1013-1020

TONIN P, SEROVA O, LENOIR G, LYNCH H, DUROCHER F, SIMARD J, MORGAN K, NAROD S (1995) BRCAl mutations in Ashkenazi Jewish women. Am J Hum Genet 57: 189

TRINCADO P, FARDELLA C, MAYERSON D, MONTERO L, OBRIEN A, BARRUETO K, GALLEGOS R (1999) Prevalencia de la deleción $185 \mathrm{AG}$ del gen BRCAl en mujeres chilenas con cáncer de mama. Rev Med Chile 127: 19-22

VALENZUELA CY (1988) On sociogenetic clines. Ethol Sociobiol 9: 259-268

VALENZUELA CY, HARB Z (1977) Socioeconomic assortative mating in Santiago, Chile: As demonstrated using stochastic matrices of mother-child relationships applied to ABO blood groups. Soc Biol 24: 225-233

VALENZUELA CY, ACUNA M, HARB Z (1987) Gradiente sociogenético en la población chilena. Rev Med Chile 115: 295-299

VAN DER LOOIJ M, WYSOCKA B, BROZEK I, JASSEM J, LIMON J, OLAH E (2000a) Founder BRCAl mutations and two novel germline BRCA2 mutations in breast and/or ovarian cancer families from NorthEastern Poland. Hum Mutat 15: 480-481

VAN DER LOOIJ M, SZABO C, BESZNYAK I, LISZKA G, CSOKAY B, PULAY T, TOTH J, DEVILEE P, KING MC, OLAH E (2000b) Prevalence of founder $B R C A 1$ and BRCA2 mutations among breast and ovarian cancer patients in Hungary. Int $\mathrm{J}$ Cancer 86: $737-740$

VEGA A, TORRES M, MARTÍNEZ JI, RUIZ-PONTE C, BARROS F, CARRACEDO A (2002) Analysis of $B R C A 1$ and $B R C A 2$ in breast and breast/ovarian cancer families shows population substructure in the Iberian Peninsula. Ann Hum Genet 66 (Pt 1): 29-36

ZHI X, SZABO C, CHOPIN S, SUTER N, WANG QS, OSTRANDER EA, SINILNIKOVA OM, LENOIR GM, GOLDGAR D, SHI YR (2002) BRCAl and BRCA2 sequence variants in Chinese breast cancer families. Hum Mutat 20: 474 